\title{
Influence of the hydrodynamic conditions on the accessibility of Aristeus antennatus and other demersal species to the deep water trawl fishery off the Balearic Islands (western Mediterranean)
}

Angel Amores*1, Lucía Rueda ${ }^{2}$, Sebastià Monserrat ${ }^{1,3}$, Beatriz Guijarro $^{2}$, Catalina Pasqual ${ }^{1}$, and Enric Massutí ${ }^{2}$

${ }^{1}$ Instituto Mediterráneo de Estudios Avanzados, IMEDEA

(UIB-CSIC). Palma de Mallorca, Spain

${ }^{2}$ Instituto Español de Oceanografía. Centre Oceanogràfic de les Balears. Moll de Ponent s/n, 07015 Palma de Mallorca, Spain

${ }^{3}$ Departament de Física. Universitat de les Illes Balears (UIB).

Palma de Mallorca, Spain

November 20, 2013

*aamores@imedea.uib-csic.es 


\begin{abstract}
Monthly catches per unit of effort (CPUE) of adult red shrimp (Aristeus antennatus), reported in the deep water bottom trawl fishery developed on the Sóller fishing ground off northern Mallorca (Western Mediterranean), and the mean ocean surface vorticity in the surrounding areas are compared between 2000 and 2010. A good correlation is found between the rises in the surrounding surface vorticity and the drops in the CPUE of the adult red shrimp. This correlation could be explained by assuming that most of the surface vorticity episodes could reach the bottom, increasing the seabed velocities and producing sediment resuspension, which could affect the near bottom water turbidity. A. antennatus would respond to this increased turbidity disappearing from the fishing grounds, probably moving downwards to the deeper waters. This massive displacement of red shrimp specimens away from the fishing grounds would consequently decrease their accessibility to fishing exploitation. Similar although more intense responses, have been observed during the downslope shelf dense water current episodes that occurred in a submarine canyon, northeast of the Iberian peninsula. The proposed mechanism suggesting how the surface vorticity observed can affect the bottom sediments is investigated using a year-long moored near-bottom current meter and a sediment trap moored near the fishing grounds.

The relationship between vorticity and catches is also explored for fish species (Galeus melastomus, Micromesistius poutassou, Phycis blennoides) and other crustacean (Geryon longipes and Nephrops norvegicus), considered as by-catch of the deep water fishery in the area. Results appear to support the suggestion that the water turbidity generated by the vorticity episodes is significant enough to affect the dynamics of the demersal species.
\end{abstract}




\section{${ }_{27} \quad 1 \quad$ Introduction}

The decapod crustacean red shrimp, Aristeus antennatus (Risso, 1816), a demersal species distributed throughout the Mediterranean and the north-eastern Atlantic, from Portugal to the Cabo Verde Islands [Arrobas and Ribeiro-Cascalho, 1987], mainly occurs in the muddy bottoms of the slope, between 400 and at least 3300 $\mathrm{m}$ [Sardà et al., 2004]. This species is one of the most valuable deep-water fishing resources in the western and central basins of the Mediterranean, remaining at a low level of exploitation in the eastern basin [Papaconstantinou and Kapiris, 2001] and revealing important bathymetric migrations [Relini et al., 2000]. However, despite its wide bathymetric distribution, it is mainly exploited between 400 and $800 \mathrm{~m} \mathrm{depth}$, and is the target species of the well-developed deep water bottom trawl fishery on the western basin slope [Sardà et al., 2003].

The trawl fleet operating off the Balearic Islands (western Mediterranean) is characterized by its versatility, which is determined by the specific dynamics of the resources, among other factors (e.g. sea conditions and fish market). Bottom trawlers not only target different species, they also change the fishing location at a given time of the year, as well as the fishing tactics during the same fishing trip. Palmer et al. [2009] defined four fishing tactics in this fishery, related to the exploitation of different bathymetric strata and target species.

The annual catches of the red shrimp in the Balearic Islands are estimated to be around $100-200 \mathrm{t}$, which represents $10 \%$ of the landings and $40 \%$ of the earnings in the trawl fishery [Guijarro et al., 2012]. Sóller, one of the most important fishing grounds for red shrimp around the Balearic Islands, is situated North of Mallorca (solid black line area in Fig. 1), where an important part of the island fleet is concentrated during the summer months [Moranta et al., 2008], when catches of large specimens occur. The red shrimp population in this fishing ground shows important seasonal variations throughout the year (such as the high abundance of juveniles recruiting to the fishing grounds in autumn-winter and the high abundance of large spawning females during the summer), compared with the other nearby fishing grounds, south of Mallorca [Guijarro et al., 2008].

The Sóller fishing ground is located on the island slope, in a well known very active area, with numerous eddies normally generated by some instabilities of the Northern current or the Balearic current (Fig. 1), particularly more intense during winter (October-March; Amores et al. [2013]). These eddies, clearly visible on satellite images, have been known to reach the deeper waters, and their effects 
63

64

65

66

67

68

69

are usually felt down to the seabed, where their velocities may increase to several times those of the mean currents measured in the zone [Amores et al., 2013]. These strong bottom currents of the order of $25 \mathrm{~cm} / \mathrm{s}$ are known to produce sediment resuspension which, in turn, may generate additional cross slope turbidity currents [Thomson et al., 2010].

In the western Mediterranean, the red shrimp distribution, and its accessibility to fishing exploitation, has been shown to be mainly influenced by geomorphology [Sardà et al., 1994, 1997] and hydrodynamics [Bombace, 1975; Demestre and Martín, 1993; Ghidalia and Bourgois, 1961; Guijarro et al., 2008; Relini and Relini, 1987; Sardà et al., 2009]. These last factors are probably linked to regional and large-scale climatic patterns [Carbonell et al., 1999; Massutí et al., 2008; Maynou, 2008]. In a recent study, Company et al. [2008] revealed that the downslope shelf dense water current events into submarine canyons, along the whole northern Catalan margin, strongly affected the red shrimp landings. This downslope shelf dense water current events is one of the main processes contributing to the shelf-deep ocean exchange [Ivanov et al., 2004], enhancing organic-matter flux and deposition, increasing suspended particulate matter concentrations and transport of organic matter from coastal zones to the deep ocean [Bosley et al., 2004; Canals et al., 2006; Company et al., 2008]. In the northern Catalan margin, it exerts a negative effect on the catches of red shrimp and a positive effect for recruitment, due to the transportation of the particulate organic matter. The increase of suspended particulate matter also appears to be related to the abundance of other crustacean species such as pandalids and penaeid [Lin et al., 1992; Puig et al., 2001] and to an enhance of benthic productivity and biodiversity inside canyon habitats [Rowe et al., 1982; Schlacher et al., 2007; Vetter et al., 2010]. In addition to downslope shelf dense water current, mesoscale eddies have also been reported to be responsible of transport of shelf sediments to the deep ocean, resuspension of bottom sediments creating turbidity layers and formation of sediment plumes around their periphery [Washburn et al., 1993]. The influence of vorticity (as indicator of eddy development) on catchability of marine species has been mostly addressed for pelagic organisms such as tuna fisheries [Hyder et al., 2009; Kai and Marsac, 2010; Ramos et al., 1996; Zainuddin et al., 2006]. However, the effect of such physical processes has also been explored for benthic species, which are also linked to variables that describe water column properties and structures [Beentjesa and Renwick, 2001; Palamara et al., 2012]. 
97 The objective of this work is to analyze the possible links between the presence

98 of eddies (which will be quantified by their associated surface vorticity) affecting

99 the Sóller fishing ground and the red shrimp yields of the deep water trawl fishery

100 developed in the area. This relationship is also explored for other demersal species

101 frequently caught by the deep water bottom trawl fishery developed in the area

102 [Guijarro and Massutí, 2006], which consist of three fishes (Galeus melastomus,

103 Micromesistius poutassou and Phycis blennoides) and two decapod crustaceans

104 (Geryon longipes and Nephrops norvegicus), with the objective of discussing their 105 different responses in relation to their living habits.

106 A year-long near-bottom current meter and a sediment trap moored near the 107 fishing grounds are used to infer the mechanism to explain how the surface vorticity 108 observed can affect the bottom sediments and, in turn, the red shrimp yields. 


\section{Data and Methods}

\subsection{Catches}

Daily time series of the landings from the bottom trawl fleet have been obtained from the official sale bills of OP Mallorca Mar, the fishery producer organization of Mallorca, between 2000 and 2010 (both years included). Each daily sale bill was assigned to one fishing tactic (FT) or a combination of them following the methodology described by Palmer et al. [2009]. Landings were standardized to CPUEs (catches per unit of effort), referred to as kilograms caught per day and boat. For $A$. antennatus, only catches obtained from the middle slope fishing tactic, developed between 600 and $800 \mathrm{~m}$ depth, have been considered, because this is the target species for this FT. Moreover, the daily sale bills distinguished red shrimp catches into two size categories (small and large) up to year 2004, and three categories (small, medium and large) from 2004 to the present day. According to Guijarro et al. [2008], two different categories were defined in order to homogenize the available data, small (including individuals with a carapace length $<32 \mathrm{~mm}$ ) and medium-large (adults, with a carapace length $\geq 32 \mathrm{~mm}$ ). For this analysis, only those of the medium-large sized category, mainly adult females, were considered. Juveniles are not taken into account for two reasons:

1. The fishing fleet mainly targets large individuals (adults) due to their higher commercial value. This fact would surely provoke a bias when trying to relate juvenile catches with abundances

2. Adult and juvenile red shrimps present a clear different bathymetric distribution. Adult individuals are mainly located at the 500-800 m range, where the fishing fleet is developed. But the highest concentrations of juveniles are situated deeper than 1000 m Sardà et al. [2003], where the bottom trawl fishery is forbidden. So juvenile catches do not properly reflect the juvenile population abundances.

From the entire fleet that currently operates in Mallorca, only five boats regularly fish in the zone of interest (Sóller) throughout the year (other boats fishing in this area only in summer are not considered). Among these five boats, exclusively two devote most of their efforts to red shrimp fishery along the middle slope and they were the only ones finally considered for the analysis. 
Finally, as a direct response to hydrodynamics changes in a daily basis is not expected, a monthly average was calculated according to the daily time series. We intentionally filtered out the high frequency variations in order to compute an integrated response in a longer time scale and take into account for the gaps in the data (that occurred, for example, on weekends or bad weather days).

Regarding the other species considered in this work (G. melastomus, M. poutassou, P. blennoides, G. longipes and N. norvegicus), all the boats and slope fishing tactics have been considered because, unlike A. antennatus, they are the 'bycatch' species of the deep water trawl fishery, and therefore, their abundance in daily landings is not as frequent as that of the red shrimp. The final time series for each species were also averaged monthly as the CPUEs in terms of $\mathrm{kg}$ of catch per day per boat.

\subsection{Hydrodynamic Data}

\subsubsection{Satellite images}

We estimated the relative vorticity $\zeta$ (from now on referred to as only vorticity) from the daily Sea Surface Height (SSH) satellite images with a map spacing of $1 / 8^{\circ} \times 1 / 8^{\circ}$, obtained from the merged satellite AVISO products available at http://www.aviso.oceanobs.com. The vorticity is calculated as the curl of the velocity field, but we only retain the third component as it represents the vorticity of a horizontal field. By considering the hydrostatic and homogeneous fluid, the final expression of $\zeta$ is:

$$
\zeta=\frac{g}{f} \cdot \nabla^{2} S S H
$$

where $g$ is the gravity acceleration, $f$ the Coriolis parameter and $\nabla^{2}$ the horizontal Laplacian.

After computing the daily vorticity fields, their absolute value was taken because both, cyclonic $(\zeta>0)$ and anticyclonic episodes $(\zeta<0)$, were expected to have the same effect on the seabed velocities and sediment resuspension. Next, we computed the spatial average in the dashed rectangle, as shown in Fig. 1. The choice of the area is somewhat arbitrary. The size should be significantly greater than the fishing ground dimension because the eddy sizes are significantly greater, and their horizontal influence is not known. The best results are found when the area is selected to be large enough to include the Northern and the Balearic cur- 
rents, potentially the eddy generators. Finally, the daily time series was averaged on a monthly basis in order to have the same time step as the time series of the catches.

\subsubsection{Moorings}

A mooring was deployed north-west of Mallorca $\left(39^{\circ} 49.682^{\prime} \mathrm{N}-02^{\circ} 12.778^{\prime} \mathrm{E}\right.$; star in Fig. 1) between November 2009 and February 2011. Located around 900 $m$ depth in the Mallorca slope, it had four CTD Seabird 37 (300, 500, 700 and $900 \mathrm{~m}$ ) and two current meters Nortek Aquadopp (500 and $900 \mathrm{~m}$ ). Moreover, the mooring had also a sediment trap placed $30 \mathrm{~m}$ above the bottom. The CTD sampling rate was 10 minutes, while the current meters recorded one value every 30 minutes. The sediment trap had a sampling interval of 10 days and it had 12 bottles. The combination of sampling rate and number of bottles made necessary a maintenance of the mooring every four months.

All the instruments operated perfectly during the entire period, except for the 500 and $900 \mathrm{~m}$ CTDs, which ran out of batteries in mid-December 2010 and mid-January 2011, respectively. The sediment trap worked well too, but the unavailability of boat lead to no recorded data between July 5 and September 21, 2010.

Sediment trap samples were wet-sieved through a $1 \mathrm{~mm}$ nylon mesh in order to retain the largest organisms. Swimmers smaller than $1 \mathrm{~mm}$ were manually removed under a dissecting microscope using fine tweezers. Finally, the sample was freeze-dried and weighed to calculate the Total Mass Flux (TMF).

Despite we did not have any direct measurement of turbidity, the Nortek Aquadopp current meters give us an estimation of it throughout the backscattering of the particles used to compute the velocity (as suggested byLohrmann [2001]). Acoustic backscattering has been used as turbidity surrogate in different references such as Thomson et al. [2010].

\subsection{Statistical Analysis}

Quantification of the similarity between surface vorticity and time series of catches was performed with the correlation function. If we define $V$ and $C$ as the monthly anomalies (time series after subtracting the mean value) for vorticity and catches, respectively, the correlation between these two series is calculated as: 


$$
\rho_{V C}(\text { lag })=\frac{1}{(N-1-\mid \text { lag } \mid) \cdot \sqrt{\sigma_{V V} \cdot \sigma_{C C}}} \begin{cases}\sum_{i=|l a g|+1}^{N} V_{i} \cdot C_{i-\mid l a g} \mid & \text { if } l a g<0 \\ \sum_{i=|l a g|+1}^{N} V_{i-\mid l a g} \cdot C_{i} & \text { if } l a g \geq 0\end{cases}
$$

${ }_{204} \quad$ with $N$ being the series length, $\sigma_{V V}$ the covariance of $V$ and $\sigma_{C C}$ the covariance 205 of $C$.

206 The significance level may be obtained with:

$$
\operatorname{sig}(\operatorname{lag})=\frac{T_{q}(0.99, N-|\operatorname{lag}|-2)}{\sqrt{N-|\operatorname{lag}|-2+\left[T_{q}(0.99, N-|\operatorname{lag}|-2)\right]^{2}}}
$$

${ }_{207}$ where $T_{q}(0.99, D)$ is the t-student distribution with a significance of $99 \%$ and $208 \mathrm{D}$ degrees of freedom. 


\section{${ }_{209} \quad 3$ Results and Discussion}

A visual inspection of the monthly average vorticity and $A$. antennatus CPUE time series appears to suggest that any increase in vorticity generally causes a decrease in the CPUEs, although a decrease in vorticity does not cause an increase in CPUEs (Fig. 2a). In fact, a negative correlation (i.e. both series are in antiphase) between time series has been found (Fig. 2b).

In the following we will give several evidences supporting the fact that surface vorticity affects red shrimp availability by modifying near bottom turbidity in the fishing grounds. If we assume that any increase in vorticity affects the CPUE of the red shrimp by producing a near bottom turbidity, which in turn would decrease the resource availability, we could not expect that the opposite, a decrease in vorticity, would immediately produce an increase in the CPUEs. Water turbidity would persist for some period of time in the area after the end of any vorticity episode and then the red shrimp response would be delayed. Therefore, the two series have been modified, trying to take into account the different, although expected, CPUE response to the increase and decrease in vorticity. Vorticity and CPUE time derivatives have been computed. As we want to highlight the part when the vorticity increases (positive derivative) and when de CPUE decreases (negative derivative), the negative vorticity and positive CPUE derivatives were artificially set at zero. Therefore, only the increases in vorticity and decreases in CPUE are considered. Furthermore, the sign of the CPUE derivatives has also been reversed for better visualization (Fig. 3a).

Vorticity and $A$. antennatus CPUE's derivative series show quite a similar pattern. The zones where the series have been forced to read zero coincide, and almost any increase in the vorticity derivative corresponds with an increase in the reversed catches derivative. The correlation between both series at lag zero, now positive due to the sign change in the CPUE's derivatives mentioned, is slightly larger than before, as expected, reaching a value of 0.48 (Fig. 3b). This result strongly supports a relationship between the increases in the surrounding absolute surface vorticity and decreases in the adult $A$. antennatus availability in the fishing grounds.

The suggested mechanism explaining the relationship observed is now supported analyzing some surface vorticity episodes recorded when the mooring was deployed in the area. During 2010, at least three of these episodes produced some footprint in the instruments deployed in the mooring line. 
The increase in the absolute value of the surface vorticity is commonly caused by the presence of an eddy, such as the one shown in Fig. 4. This particular eddy remained in the area between mid-November and mid-December 2010 and was studied in detail by Amores et al. [2013]. This eddy was clearly reflected in the currents registered at 500 and $900 \mathrm{~m}$ depth. A significant velocity increase was measured at both depths (episode 3 in Fig. 5a and 5b). Velocities showed spikes reaching up to $26 \mathrm{~cm} / \mathrm{s}$ at $900 \mathrm{~m}$, where the mean current during the whole year was computed to be around $5 \mathrm{~cm} / \mathrm{s}$. This eddy also affected the current direction, causing a complete reversal in the currents at $500 \mathrm{~m}$ (Fig. 5c) and a down slope gyre at $900 \mathrm{~m}$ (Fig. 5d).

This particular eddy clearly reached down to the bottom, and the recorded gyres and velocity increases could easily have caused the material resuspension. This hypothesis is supported by three indirect measurements:

1. the increase in the total flux mass (TFM) recorded by the moored sediment trap at the time of the eddy (Fig. 6)

2. the increase of the acoustic backscattering during the episode (Fig. 7a)

3. the clear down slope gyre at $900 \mathrm{~m}$ which could be related to a near bottom turbidity current (Fig 5d).

The eddy shown in Fig. 4 was not the only one recorded when the mooring was deployed. Another eddy, which occurred between mid-January and March 2010, was also measured by the mooring (episode 1 in Fig. 5). This eddy too reached the bottom, although with a weaker footprint in velocity. However, the TFM still reached similar values to those observed during the December 2010 eddy and an increase in backscattering is also observed.

Still another gyre was observed between June and July 2010; however, it was only noticeable at $500 \mathrm{~m}$ (episode 2 in Fig. 5). Its effect at $900 \mathrm{~m}$ was weak. Even so, a TFM peak was also measured by the sediment trap, although much weaker than during the other two eddies (Fig. 6). Backscattering did not show any significant increase during this episode. This could be explained by the steep slope of the area. Even if the eddy was not energetic enough to reach down to $900 \mathrm{~m}$ depth, where the mooring was deployed, it could still affect the bottom at shallower depths and the resuspension of material could have reached deeper waters, causing the increased TFM that is recorded in the sediment trap. 
From the above described episodes, it has been observed that the surface eddies exert some degree of influence on the seabed dynamics and that might increase the water turbidity near the bottom and affect the availability of $A$. antennatus in the fishing grounds. This mechanism can be better visualized by restricting the time interval to a shorter period of time of some of the data shown in Fig. 2, for the period, 2006-2010 (Fig. 8). During these years, the vorticity episodes are time spaced enough to allow an almost complete recovery towards a normal situation after any episode, before the arrival of the next one. The mechanism suggested are then better observed in the data. A vorticity increase (dark gray bands in Fig. 8) would trigger an increase in the re-suspended material and would force A. antennatus to move away from the fishing ground, probably towards greater depths, leading to a decrease in the catches of this species. This scenario would remain unchanged until the eddy effects disappear and the sediments once again precipitate to the sea floor (soft gray bands in Fig. 8). Once all the sediments are completely settled down, the water conditions would become suitable to allow the individuals to return to the depths where they can be caught (white bands in Fig. 8). Four episodes appear to follow one after another in the period shown.

Company et al. [2008] described a similar but stronger phenomenon in the submarine canyon system off the north-eastern Iberian Peninsula. They found a correlation between the strong currents associated with intense downslope shelf dense water current events and the disappearance of A. antennatus from its fishing grounds, exerting a negative effect on the catches reporting and a temporary collapse of its fishery. An increase in the mortality rated after exposure to high turbidity has also been detected for Penaeid shrimps at juvenile and adult stages [Lin et al., 1992]. Both downslope shelf dense water current events and mesoscale eddies have been reported to enhance organic-matter flux and deposition, increasing suspending particulate matter concentrations with the transport of organic matter from coastal zones to the deep ocean or by resuspension of bottom sediments [Bosley et al., 2004; Canals et al., 2006; Washburn et al., 1993]. Life forms as diverse as phytoplankton, protozoans, crustaceans, fish, sea snakes, marine mammals and birds are found to alter their distributions in the presence of such flow patterns [Owen, 1981], which can be responsible for enhancing benthic productivity and biodiversity inside canyon habitats [Rowe et al., 1982; Schlacher et al., 2007; Vetter et al., 2010]. The presence of a significant amount of suspended sediment has also been related to the higher occurrence of juveniles and females 
of the deep-water pandalid shrimp species, genus Plesionika [Puig et al., 2001] and the regions where the intermediate nepheloid layers detach from the seabed have been defined as potential deep-water nursery habitats for these species. The transportation of the particulate organic matter associated with the downslope shelf dense water current appears to be positive for recruitment of red shrimp in the north-eastern Ibearian Peninsula [Company et al., 2008], with a positive increase in the landings 3-5 years after these events, preceded by an increase in the number of juveniles. However, this last effect has not been detected off the Balearic Islands, probably because of the slight difference in the feeding strategies of the species between the north-eastern Iberian Peninsula and the Balearic Islands. A. antennatus has a highly varied diet, being among the mega-benthic species mainly preying on the benthos in the deep Mediterranean [Cartes, 1994; Cartes and Carrassón, 2004]. However, benthic preys are particularly significant off the north-eastern Iberian Peninsula, where the submarine canyons enhance such types of food availability. Conversely, the trophic webs off the Balearic Islands show an impoverishment of the benthos biomass and depend more directly on food of planktonic origin, enhancing the consumption of micro-nektonic preys [Cartes et al., 2008; Maynou and Cartes, 2000]. In this sense, the positive effects of downslope shelf dense water current and sediment resuspension in the long term should be also more marked off north-eastern Iberian Peninsula than off the Balearic Islands.

Although the mechanism suggested is somehow speculative because we have to rely on indirect data (backscattering) to deduce bottom turbidity, we have shown several evidences that the presence of enough energetic eddies may cause bottom turbidity increases in the fishing ground. Still another indirect evidence supporting the mechanism suggested comes from the analysis of other demersal species caught in the same region that also appear to be related to vorticity changes in the area. The correlations found for each species (Fig. 9) are different from those observed for $A$. antennatus but consistent with the suggested mechanism where vorticity affects the seabed by increasing the bottom water turbidity.

Other decapod crustaceans, Geryon longipes and Nephrops norvegicus, the more sedentary and benthic species, show a significant positive correlation to the vorticity events at around 0.4 and 0.5 , respectively. These two species are closely connected to the bottom, as reflected by their feeding behavior and biological characteristics. G. longipes preys on a broad range of benthic invertebrates [Cartes, 
347 1993] and $N$. norvegicus shows a scavenging activity [Cristo and Cartes, 1998]

348 and has been related to the sediment characteristics [Maynou and Sardà, 1997].

349 Unlike A. antennatus, it is likely that these two species may take some advantage 350 of the re-suspended matter.

${ }_{351}$ Galeus melastomus, which has more mobility than the previously considered 352 epi-benthic species, feeds on the mesopelagic preys with the occasional occurrence 353 of benthic feeding activity and scavenging in the adult phase [Fanelli et al., 2009]. 354 This species showed a lower correlation (0.33) with the vorticity time series.

355 Finally, Micromesistius poutassou and Phycis blennoides, the two bentho356 pelagic teleosts with greater capacity of movement above the bottom, are expected 357 to be less affected by bottom water turbidity. In fact, no significant correlations 358 between the CPUEs and vorticity have been found. 


\section{3s 4 Summary and Conclusions}

A reasonable good negative correlation is noted between the monthly CPUE of the adult A. antennatus bottom trawl yields in the fishing grounds off northern Mallorca and the mean surface vorticity in the surrounding area. We have shown that the eddies causing the vorticity events may reach the bottom, increasing the current velocities, which in turn would trigger sediment resuspension and increased bottom water turbidity. Such a change in the water conditions would force adult $A$. antennatus individuals to move away from the fishing ground, probably downwards, to greater depths. This proposed mechanism is similar, although lower in magnitude, to the one suggested by Company et al. [2008] in the downslope shelf dense water current events of the submarine canyons in the northern Catalan margin, off the north-eastern Iberian Peninsula. In the Balearic Islands, where these geomorphological structures do not exist and where there is no river runoff, the eddies would be the triggering factor.

Other deep water demersal species found along with the catch of the red shrimp fishery, possessing different behavior and feeding habits, exhibit different responses to these events, but all of them are consistent with the eddy generation near bottom velocities increase and bottom water turbidity.

A final hypothesis could also be suggested from the results obtained. The seasonal migration of most of the fishing fleet of Mallorca, targeting the red shrimp in the Sóller fishing grounds during the summer has been explained by the highest abundance of large spawning females in this area during this season [Guijarro et al., 2008], similar to other areas off the north-eastern Iberian Peninsula [Sardà et al., 1994, 1997]. In light of this, the absence of these large aggregations in the Sóller fishing grounds during the rest of the year could be related to the particular behavior of the species. However, it is worth noting that, according to Amores et al. [2013], the vorticity episodes are much more intense off northern Mallorca during the winter time (October to March) than in the summer. This fact could be an additional factor explaining the decrease in the availability of the red shrimp to fishing exploitation during these months. However, off southern Mallorca, yields from the bottom trawl fishery targeting to red shrimp remain more stable [Guijarro et al., 2008]. 


\section{${ }_{301}$ Acknowlegments}

392 This research has been partially sponsored by the IDEADOS project (CMT2008-

${ }_{393}$ 04489-C03-01 and 03). The work of A. Amores has been funded by a JAE-PreDoc

394 grant from Consejo Superior de Investigaciones Científicas (CSIC) and co-funded

395 by Programa Operativo FSE 2007-2013. The authors are grateful to the fishermen

396 associations in Palma and the Autonomous Government of the Balearic Islands

397 for providing landing data. The authors also wish to express their gratitude to

398 the IDEADOS team for their collaboration in the data acquisition process and

399 the crews of the $\mathrm{R} / \mathrm{V}$ Odón de Buen and $\mathrm{F} / \mathrm{V}$ Punta des Vent for their valuable

400 assistance during the mooring deployment. 


\section{${ }_{401}$ References}

Amores, A., Monserrat, S., Marcos, M., 2013. Vertical structure and temporal evolution of an anticyclonic eddy in the balearic sea (western mediterranean). J. Geophys. Res. Oceans 118-4, 2097-2106.

Arrobas, I., Ribeiro-Cascalho, A., 1987. On the biology and fishery of aristeus antennatus (risso, 1816) in the south portuguese coast. Inv. Pesq. 51 (suppl. 1), 233-243.

Beentjesa, M. P., Renwick, J. A., 2001. The relationship between red cod, pseudophycis bachus, recruitment and environmental variables in new zealand. Environmental Biology of Fishes 61 (3), 315-328.

Bombace, G., 1975. Considerazioni sulla distribuzione delle popolazioni di livello batiale con particolare riferimento a quelle bentoniche. Pubbl. Staz. Zool. Napoli 39 (suppl 1), 7-21.

Bosley, K. L., Lavelle, J. W., Brodeur, R. D., Wakefield, W. W., Emmett, R. L., Baker, E. T., Rehmke, K. M., 2004. Biological and physical processes in and around astoria submarine canyon, oregon, $\{\mathrm{USA}\}$. Journal of Marine Systems $50(1-2), 21-37$.

Canals, M., Puig, P., de Madron, X. D., Heussner, S., Palanques, A., Fabres, J., 2006. Flushing submarine canyons. Nature 444 (7117), 354-357.

Carbonell, A., Carbonell, M., Demestre, M., Grau, A., Monserrat, S., 1999. The red shrimp aristeus antennatus (risso, 1816) fishery and biology in the balearic islands, western mediterranean. Fisheries Research 44, 1-13.

Cartes, J. E., 1993. Diets of deep-sea brachyuran crabs in the western mediterranean sea. Marine Biology 117, 449-457.

Cartes, J. E., 1994. Influence of depth and season on the diet of the deep-water aristeid aristeus antennatus along the continental slope (400 to $2300 \mathrm{~m}$ ) in the catalan sea (western mediterranean). Marine Biology 120, 639-648.

Cartes, J. E., Carrassón, M., 2004. Influence of trophic variables on the depthrange distributions and zonation rates of deep-sea megafauna: the case of the western mediterranean assemblages. Deep Sea Research Part I: Oceanographic Research Papers 51, 263-279. 
Cartes, J. E., Papiol, V., Guijarro, B., 2008. The feeding and diet of the deep-sea shrimp aristeus antennatus off the balearic islands (western mediterranean): Influence of environmental factors and relationship with the biological cycle. Progress in Oceanography 79, 37-54.

Company, J. B., Puig, P., Sardà, F., Palanques, A., Latasa, M., Scharek, R., 2008. Climate influence on deep sea populations. PLoS ONE 3, e1431.

Cristo, M., Cartes, J. E., 1998. A comparative study of the feeding ecology of nephrops norvegicus (1.), (decapoda: Nephropidae) in the bathyal mediterranean and the adjacent atlantic. Scientia Marina 62 (Suppl. 1), 81-90.

Demestre, M., Martín, P., 1993. Optimum exploitation of a demersal resource in the western mediterranean: the fishery of the deep-water shrimp aristeus antennatus (risso, 1816). Scientia Marina 57 (2-3), 175-182.

Fanelli, E., Rey, J., Torres, P., de Sola, L. G., 2009. Feeding habits of blackmouth catshark galeus melastomus rafinesque, 1810 and velvet belly lantern shark etmopterus spinax (linnaeus, 1758) in the western mediterranean. J. Appl. Ichthyol. 25 (Suppl. 1), 83-93.

Ghidalia, W., Bourgois, F., 1961. Influence of temperature and light on the distribution of shrimps in medium and great depths. Gfcm Studies and Reviews 16,49 .

Guijarro, B., Fanelli, E., Moranta, J., Cartes, J. E., Massutí, E., 2012. Small-scale differences in the distribution and population dynamics of pandalid shrimps in the western mediterranean in relation to environmental factors. Fisheries Research 119-120, 33-47.

Guijarro, B., Massutí, E., 2006. Selectivity of diamond- and square-mesh codends in the deepwater crustacean trawl fishery off the balearic islands (western mediterranean). ICES J. Mar. Sci. 63 (1), 52-67.

Guijarro, B., Massutí, E., Moranta, J., Díaz, P., 2008. Population dynamics of the red shrimp aristeus antennatus in the balearic islands (western mediterranean): Short spatio-temporal differences and influence of environmental factors. Journal of Marine Systems 71 (3-4), 385-402. 
Hyder, P., Bigelow, K., Brainard, R., Seki, M., Firing, J., Flament, P., 2009. Migration and abundance of bigeye tuna (Thunnus obesus), and other pelagic species, inferred from catch rates and their relation to variations in the ocean environment. SOEST 09-02.

Ivanov, V., Shapiro, G., Huthnance, J., Aleynik, D., Golovin, P., 2004. Cascades of dense water around the world ocean. Progress in Oceanography 60 (1), 47 98.

Kai, E. T., Marsac, F., 2010. Influence of mesoscale eddies on spatial structuring of top predators' communities in the mozambique channel. Progress in Oceanography $86(1-2), 214-223$.

Lin, H.-P., Charmantier, G., Thuet, P., Trilles, J.-P., 1992. Effects of turbidity on survival, osmoregulation and gill $\mathrm{na}^{+}-\mathrm{k}^{+}$atpase in juvenile shrimp Penaeus japonicus. Marine Ecology Progress Series 90, 31-37.

URL http://www.int-res.com/articles/meps/90/m090p031.pdf

Lohrmann, A., 2001. Monitoring sediment concentration with acoustic backscattering instruments. Nortek Tech. notes No. N4000-712.

Massutí, E., Monserrat, S., Oliver, P., Moranta, J., López-Jurado, J. L., Marcos, M., Hidalgo, J. M., Guijarro, B., Carbonell, A., Pereda, P., 2008. The influence of oceanographic scenarios on the population dynamics of demersal resources in the western mediterranean: Hypothesis for hake and red shrimp off balearic islands. Journal of Marine Systems 71 (3-4), 421-438.

Maynou, F., 2008. Environmental causes of the fluctuations of red shrimp (aristeus antennatus) landings in the catalan sea. Journal of Marine Systems 71 (3-4), 294-302.

Maynou, F., Cartes, J. E., 2000. Community structure of bathyal decapod crustaceans off south-west balearic islands (western mediterranean): seasonality and regional patterns in zonation. Journal of the Marine Biological Association of the United Kingdom 80, 789-798.

Maynou, F., Sardà, F., 1997. Nephrops norvegicus population and morphometrical characteristics in relation to substrate heterogeneity. Fisheries Research 30 (12), 139-149. 
Moranta, J., Quetglas, A., Massutí, E., Guijarro, B., Hidalgo, M., Diaz, P., 2008. Spatio-temporal variations in deep-sea demersal communities off the balearic islands (western mediterranean). Journal of Marine Systems 71 (3-4), 346-366.

Owen, R. W., 1981. Fronts and eddies in the sea: mechanisms, interactions and biological effects. Analysis of marine ecosystems, 197-233.

URL http://swfsc.noaa.gov/publications/cr/1981/8149.pdf

Palamara, L., Manderson, J., Kohut, J., Oliver, M. J., Gray, S., Goff, J., 2012. Improving habitat models by incorporating pelagic measurements from coastal ocean observatories. Marine Ecology Progress Series 447, 15-30.

Palmer, M., Quetglas, A., Guijarro, B., J.Moranta, Ordines, F., Massutí, E., 2009. Performance of artificial neural networks and discriminant analysis in predicting fishing tactics from multispecific fisheries. Canadian Journal of Fisheries and Aquatic Sciences 66, 224-237.

Papaconstantinou, C., Kapiris, K., 2001. Distribution and population structure of the red shrimp (aristeus antennatus) on an unexploited fishing ground in the greek ionian sea. Aquatic Living Resources 14, 303-312.

Puig, P., Company, J. B., Sardà, F., Palanques, A., 2001. Responses of deep-water shrimp populations to intermediate nepheloid layer detachments on the northwestern mediterranean continental margin. Deep Sea Research Part I: Oceanographic Research Papers 48, 2195-2207.

Ramos, A. G., Santiago, J., Sangra, P., Canton, M., 1996. An application of satellite-derived sea surface temperature data to the skipjack (katsuwonus pelamis linnaeus, 1758) and albacore tuna (thunnus alalunga bonaterre, 1788) fisheries in the north-east atlantic. International Journal of Remote Sensing 17 (4), 749-759.

Relini, G., Relini, L. O., 1987. The decline of red-shrimp stocks in the gulf of genoa. Investigacion Pesquera 51, 245-260.

Relini, M., Maiorano, P., D’Onghia, G., Relini, L. O., Tursi, A., Panza, M., 2000. A pilot experiment of tagging the deep shrimp aristeus antennatus (risso, 1816). Scientia Marina 64, 357-361. 
Rowe, G. T., Polloni, P. T., Haedrich, R. L., 1982. The deep-sea macrobenthos on the continental margin of the northwest atlantic ocean. Deep Sea Research Part A. Oceanographic Research Papers 29 (2), 257 - 278.

Sardà, F., Cartes, J. E., Norbis, W., 1994. Spatia-temporal structure of the deepwater shrimp aristeus antennatus (decapoda: Aristeidae) population in the western mediterranean. Fishery Bulletin 92, 599-607.

Sardà, F., Company, J. B., Bahamón, N., Rotllant, G., Flexas, M. M., Sánchez, J. D., niga, D. Z., Coenjaerts, J., Orellana, D., Jordà, G., Puigdefábregas, J., Sánchez-Vidal, A., Calafat, A., Martín, D., Espino, M., 2009. Relationship between environment and the occurrence of the deep-water rose shrimp aristeus antennatus (risso, 1816) in the blanes submarine canyon (nw mediterranean). Progress in Oceanography 82, 227-238.

Sardà, F., Company, J. B., Maynou, F., 2003. Deep-sea shrimp (aristeus antennatus risso 1816) in the catalan sea: a review and perspectives. J. Northw. Atl. Fish. Sci 31, 117-136.

Sardà, F., D’Onghia, G., Politou, C. Y., Company, J. B., Maiorano, P., Kapiris, K., 2004. Deep-sea distribution, biological and ecological aspects of aristeus antennatus ( risso, 1816) in the western and central mediterranean sea. Scientia Marina 68, 117-127.

Sardà, F., Maynou, F., Talló, L., 1997. Seasonal and spatial mobility patterns of rose shrimp aristeus antennatus in the western mediterranean: results of a long-term study. Marine Ecology Progress Series 159, 133-141.

Schlacher, T. A., Schlacher-Hoenlinger, M. A., Williams, A., Althaus, F., Hooper, J. N. A., Kloser, R., 2007. Richness and distribution of sponge megabenthos in continental margin canyons off southeastern australia. Marine Ecology Progress Series 340, 73-88.

Thomson, R. E., Davis, E. E., Heesemann, M., Villinger, H., 2010. Observations of long-duration episodic bottom currents in the middle america trench: Evidence for tidally initiated turbidity flow. J. Geophys. Res. 115, C10020.

Vetter, E. W., Smith, C. R., de Leo, F. C., 2010. Hawaiian hotspots: enhanced megafaunal abundance and diversity in submarine canyons on the oceanic islands of hawaii. Marine Ecology 31 (1), 183-199. 
555 Washburn, L., Swenson, M. S., Largier, J. L., Kosro, P. M., Ramp, S. R., 1993.

${ }_{556}$ Cross-shelf sediment transport by an anticyclonic eddy off northern california.

$557 \quad$ Science 261 (5128), 1560-1564.

${ }_{558}$ Zainuddin, M., Kiyofuji, H., Saitoh, K., Saitoh, S.-I., 2006. Using multi-sensor

559 satellite remote sensing and catch data to detect ocean hot spots for albacore

${ }_{560}$ (thunnus alalunga) in the northwestern north pacific. Deep Sea Research Part

561 II: Topical Studies in Oceanography 53 (3-4), 419 - 431. 


\section{${ }_{562}$ Figure Captions}

563

595

Fig. 1. Map of the studied area in the western Mediterranean. The unbroken line encloses Sóller fishing grounds where Aristeus antennatus is exploited and the broken line corresponds to the zone where the time series of vorticity has been calculated. Mooring location is indicated by a star.

Fig. 2. a) Monthly averaged time series of vorticity (black) and Aristeus antennatus CPUE's (green). b) Correlation between these two series, showing the maximum correlation $(-0.35)$ around lag 0 . Black line represents the $95 \%$ confidence level.

Fig. 3. a) Derivative time series of vorticity (black) and Aristeus antennatus CPUE's (green). In the series of the vorticity derivative, the negative values have been fixed at 0 , while the positive values of the derivative CPUE's series have been set at 0 . Notice that the last one has suffered a change of sign. b) Correlation between these two series show the maximum value (0.48) at lag 0 . Black line represents the $95 \%$ confidence level.

Fig. 4. Sea Surface Height (SSH) image from December 1, 2010. It shows an eddy in the region analyzed. The star shows the mooring position.

Fig. 5. 24h low-pass filtered speed series of 500 (a) and 900 (b) m depth current meters of the mooring for the whole recorded period. Blue indicates the low speed values degrading to red, which indicates the high values. (c) and (d) are the progressive vector diagrams for 500 and $900 \mathrm{~m}$ depth, respectively. The different colors coincide temporally with the speed time series. Enclosed areas represent moments where an eddy is present in the zone. Ellipse number 1 highlight an eddy which is strongly present at $500 \mathrm{~m}$ depth, but weakly present at $900 \mathrm{~m}$; number 2 ellipse shows an eddy which reached to $500 \mathrm{~m}$ depth, although not right up to $900 \mathrm{~m}$; and number 3 ellipse illustrates an eddy which arrived strongly to the 500 and $900 \mathrm{~m}$ depths. Note that in the PVDs the ratio between the scales of $\mathrm{x}$ and $\mathrm{y}$ axis is $2: 1$.

Fig. 6. Total Flux Mass (TFM) collected by the sediment trap during the whole 
597 sampling time. The gap in the data is due to the unavailability of ship for carrying

${ }_{598}$ out the mooring maintenance. The dashed ellipses show the increment of TFM

599 due to the eddies reported in Fig. 5.

600

601 Fig. 7. Acoustic backscattering (a) and speed (b) measured by the $900 \mathrm{~m}$ current ${ }_{602}$ meter during the third episode.

603

604 Fig. 8. Zoom of the Fig. 2, where the effect of the vorticity (blue) on the Aristeus 605 antennatus CPUE's (green) can be seen. The colored bands indicate the amount 606 of particles that would be re-suspended.

607

${ }_{608}$ Fig. 9. Time series of CPUE's for five demersal species (by catch) from the deep 609 water trawl fishery and its correlation with the absolute value of surface vorticity. 


\section{0 \\ Figures}

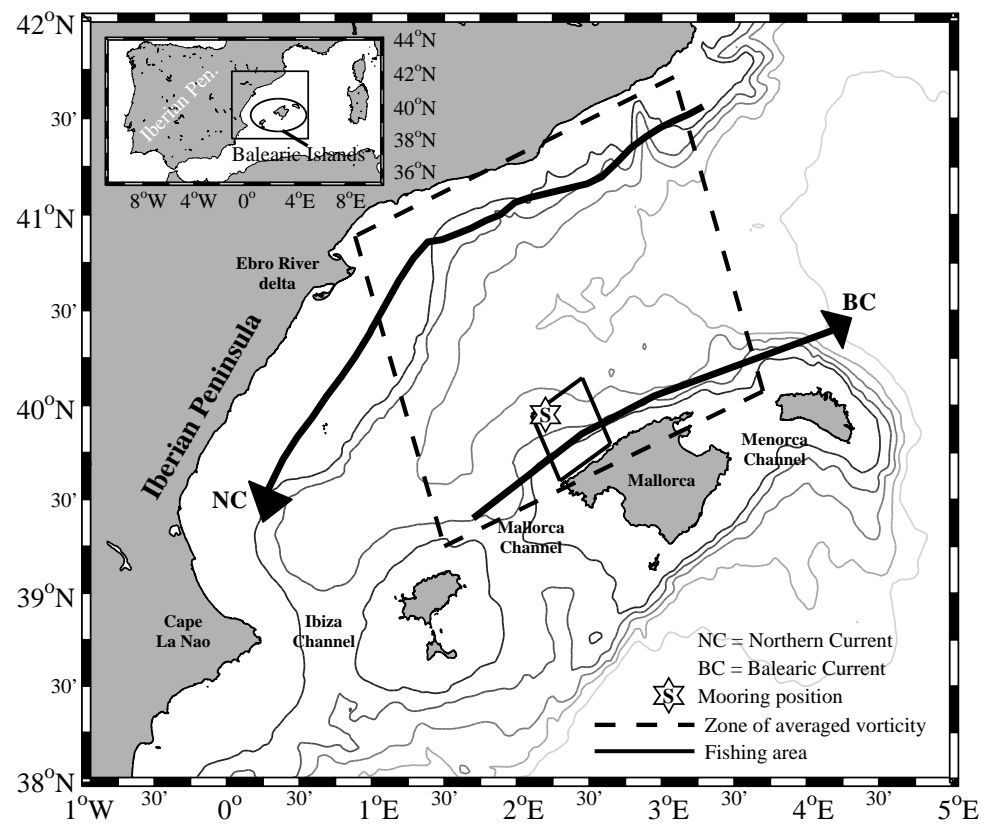

Figure 1: Map of the studied area in the western Mediterranean. The unbroken line encloses Sóller fishing grounds where Aristeus antennatus is exploited and the broken line corresponds to the zone where the time series of vorticity has been calculated. Mooring location is indicated by a star. 


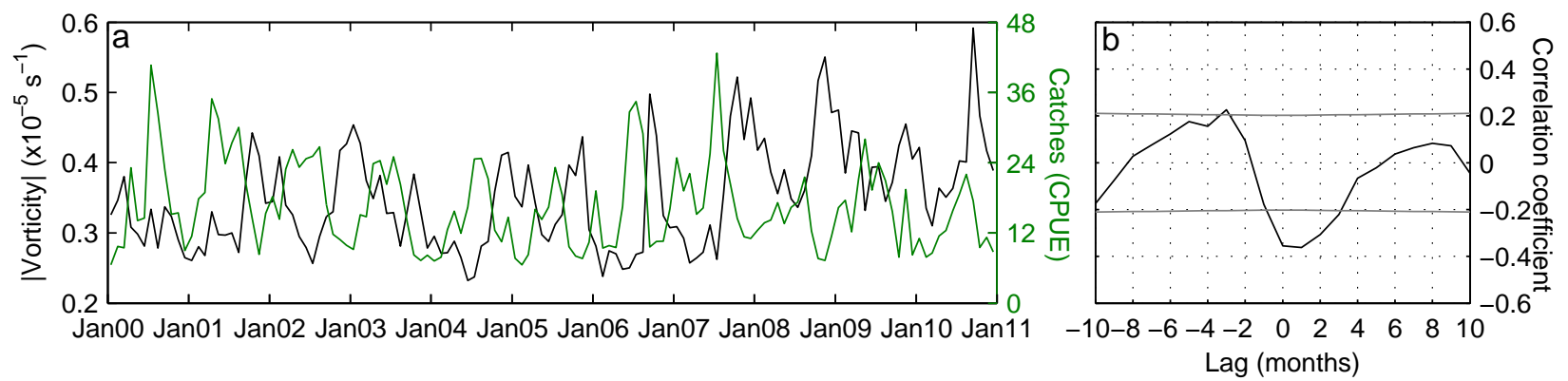

Figure 2: a) Monthly averaged time series of vorticity (black) and Aristeus antennatus CPUE's (green). b) Correlation between these two series, showing the maximum correlation (-0.35) around lag 0. Black line represents the $95 \%$ confidence level.
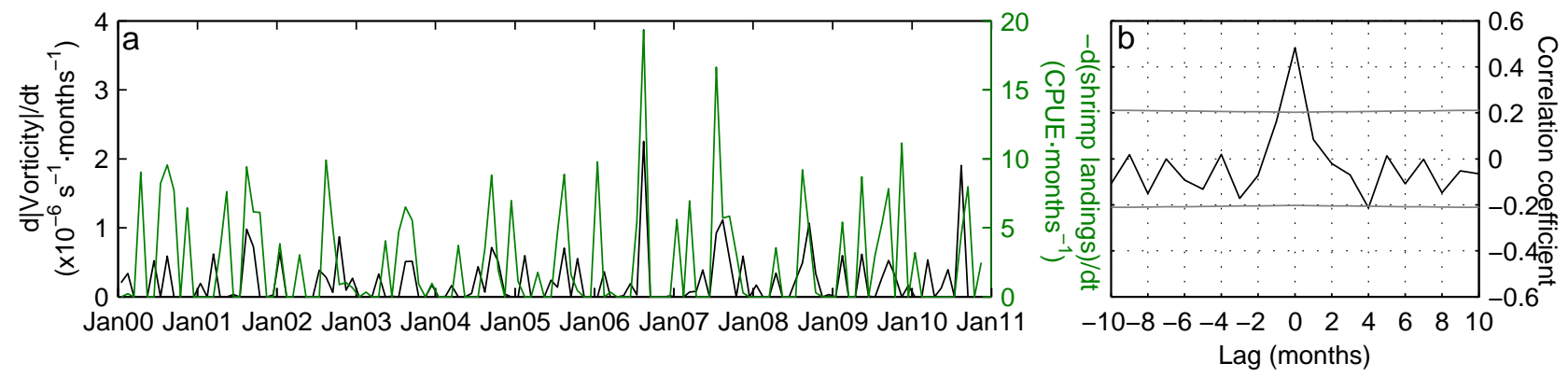

Figure 3: a) Derivative time series of vorticity (black) and Aristeus antennatus CPUE's (green). In the series of the vorticity derivative, the negative values have been fixed at 0 , while the positive values of the derivative CPUE's series have been set at 0 . Notice that the last one has suffered a change of sign. b) Correlation between these two series show the maximum value (0.48) at lag 0 . Black line represents the $95 \%$ confidence level. 


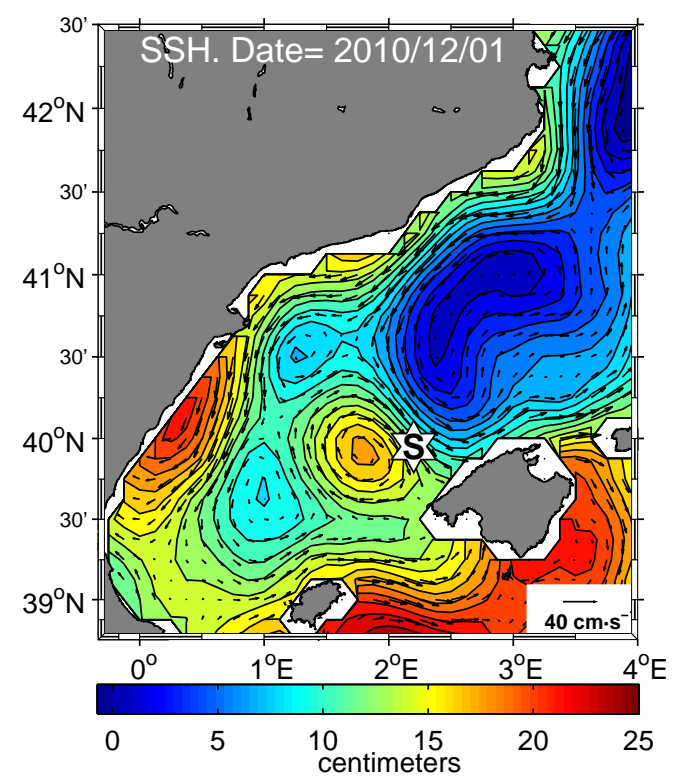

Figure 4: Sea Surface Height (SSH) image from December 1, 2010. It shows an eddy in the region analyzed. The star shows the mooring position. 

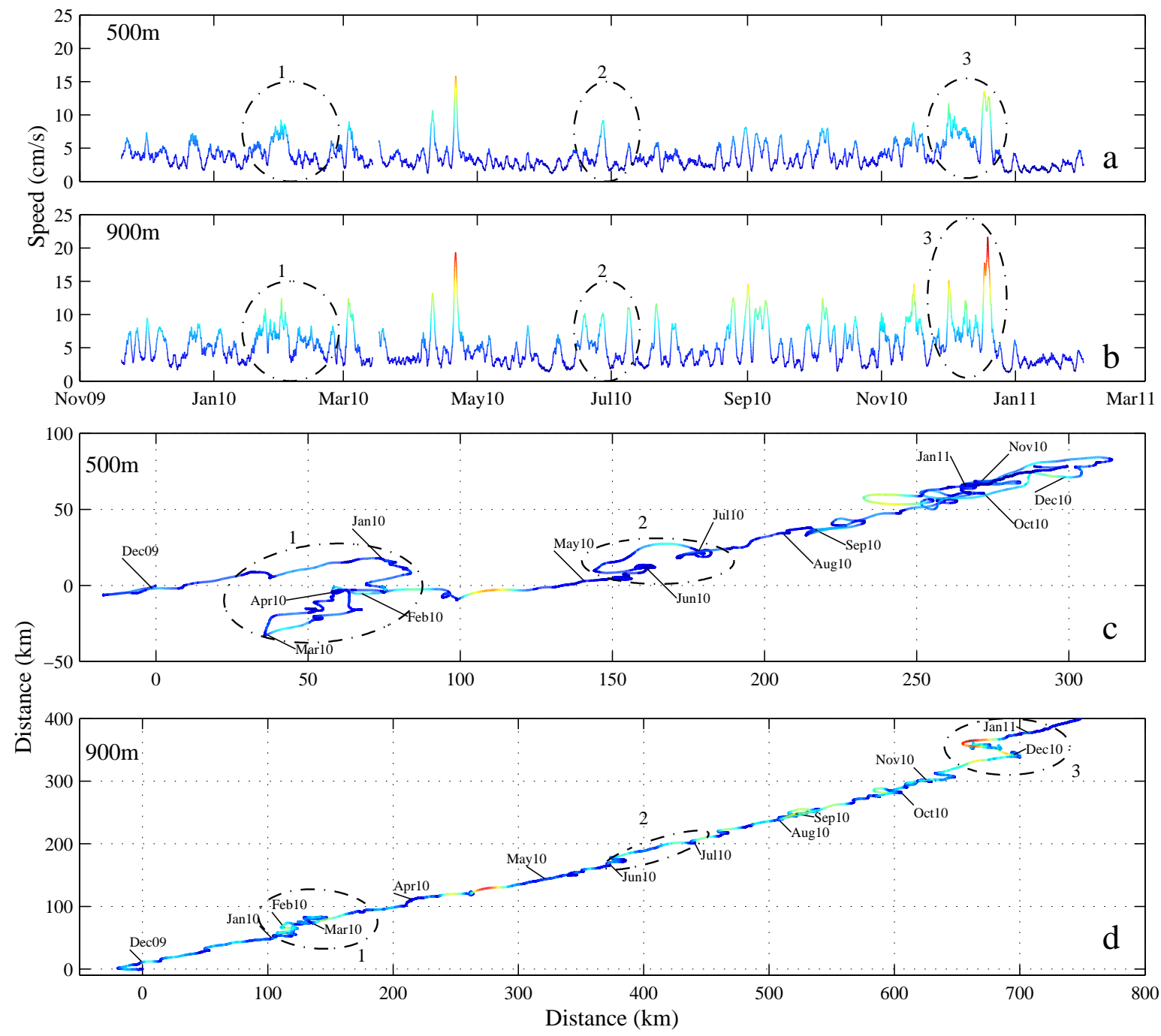

Figure 5: 24h low-pass filtered speed series of 500 (a) and 900 (b) m depth current meters of the mooring for the whole recorded period. Blue indicates the low speed values degrading to red, which indicates the high values. (c) and (d) are the progressive vector diagrams for 500 and $900 \mathrm{~m}$ depth, respectively. The different colors coincide temporally with the speed time series. Enclosed areas represent moments where an eddy is present in the zone. Ellipse number 1 highlight an eddy which is strongly present at $500 \mathrm{~m}$ depth, but weakly present at $900 \mathrm{~m}$; number 2 ellipse shows an eddy which reached to $500 \mathrm{~m}$ depth, although not right up to $900 \mathrm{~m}$; and number 3 ellipse illustrates an eddy which arrived strongly to the 500 and $900 \mathrm{~m}$ depths. Note that in the PVDs the ratio between the scales of $\mathrm{x}$ and $\mathrm{y}$ axis is $2: 1$. 


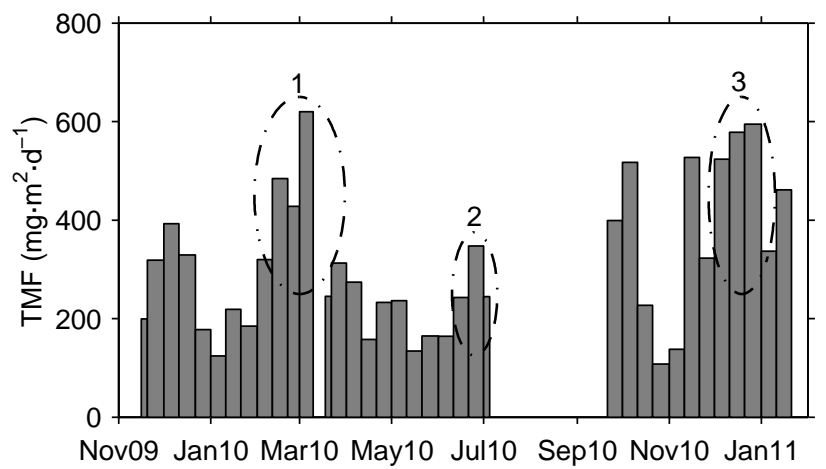

Figure 6: Total Flux Mass (TFM) collected by the sediment trap during the whole sampling time. The gap in the data is due to the unavailability of ship for carrying out the mooring maintenance. The dashed ellipses show the increment of TFM due to the eddies reported in Fig. 5.
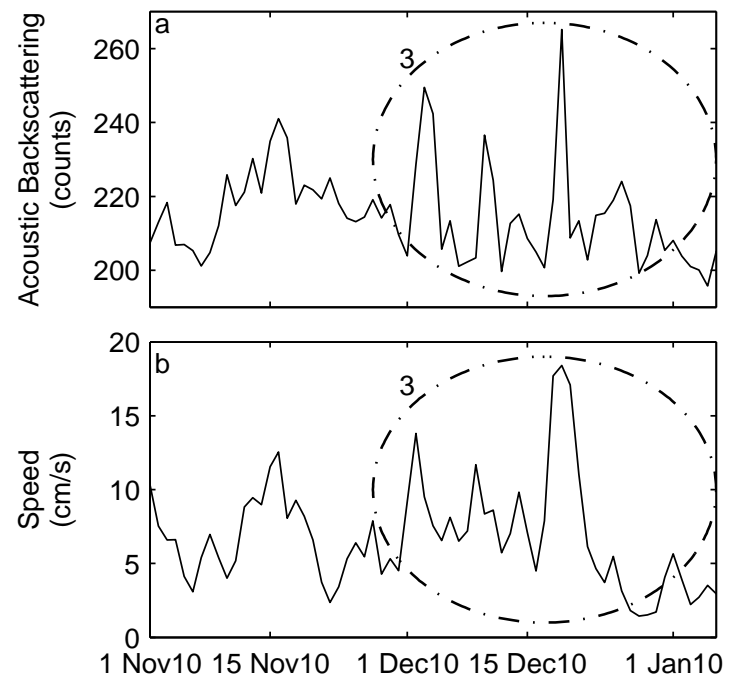

Figure 7: Acoustic backscattering (a) and speed (b) measured by the $900 \mathrm{~m}$ current meter during the third episode. 


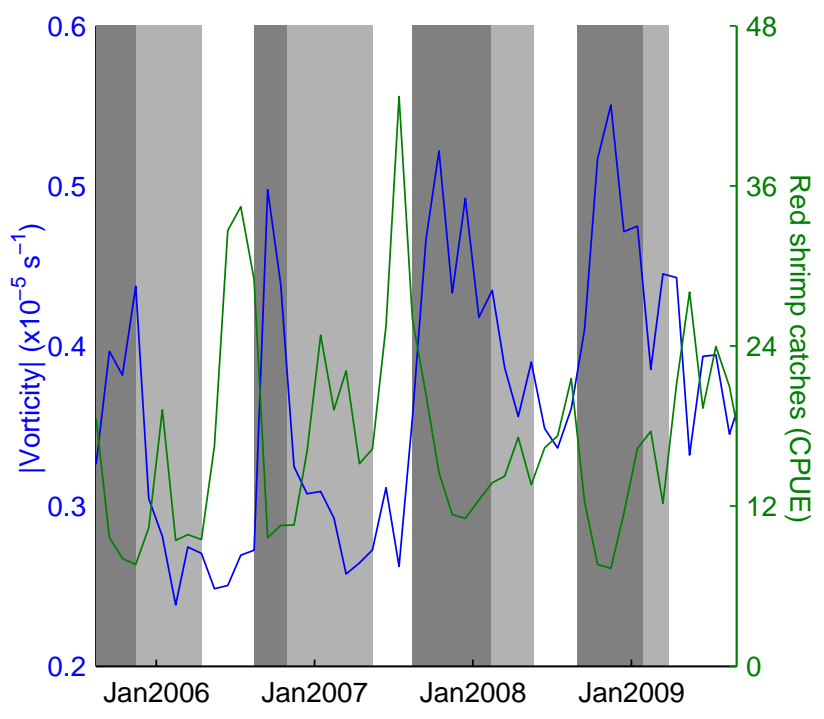

Figure 8: Zoom of the Fig. 2, where the effect of the vorticity (blue) on the Aristeus antennatus CPUE's (green) can be seen. The colored bands indicate the amount of particles that would be re-suspended. 


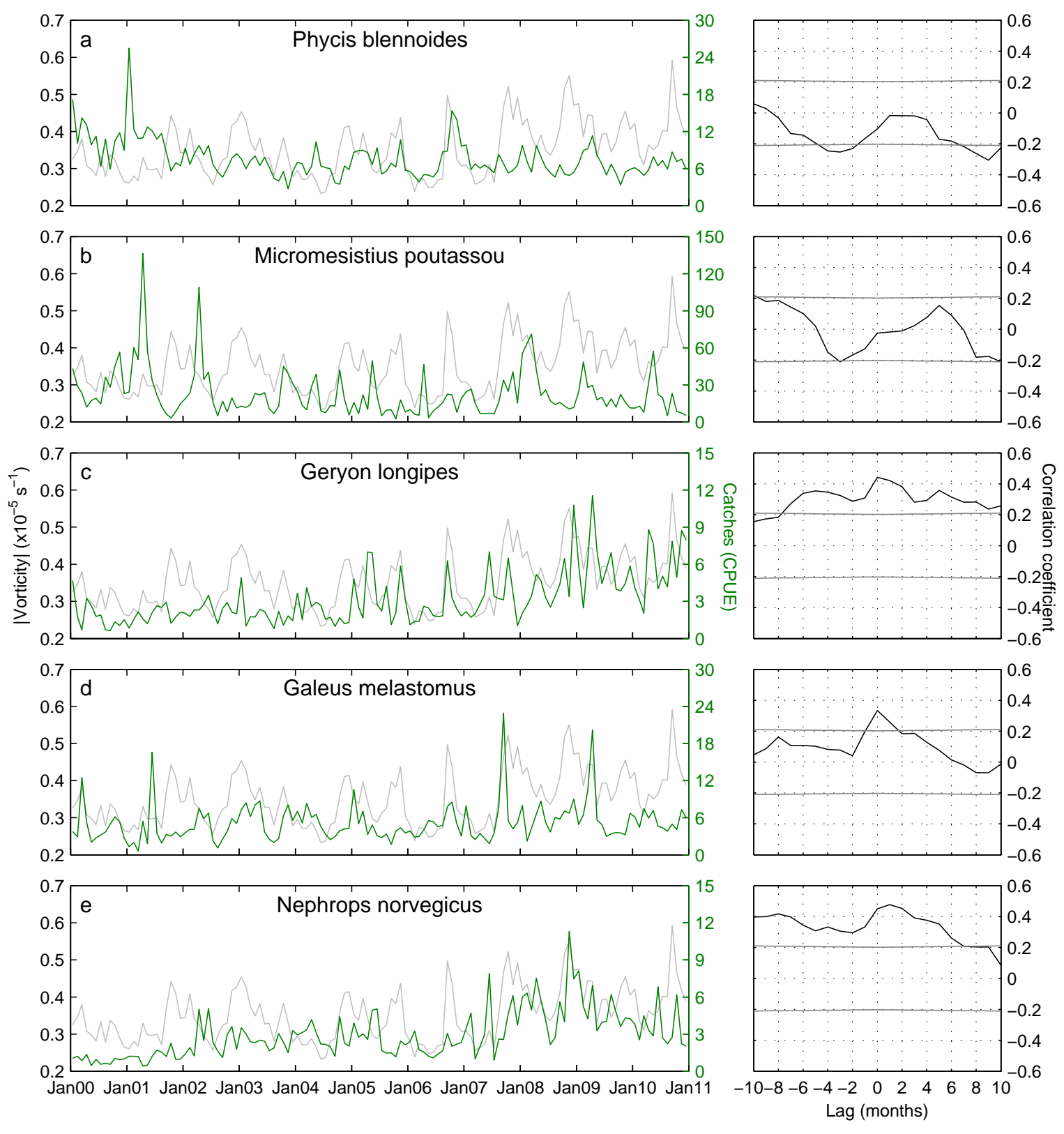

Figure 9: Time series of CPUE's for five demersal species (by catch) from the deep water trawl fishery and its correlation with the absolute value of surface vorticity. 